\title{
Three Forms of Environmental Taxation
}

\author{
Barry Bracewell-Milnes, Banstead
}

\section{Introduction}

Environmental concerns have become increasingly important over the last decade, and this trend is likely to continue. The form these concerns take may be helpful or harmful not, however, only to the economy but even to the environment.

\section{Regulation, or taxes on emissions}

The prohibition of certain activities, or their discouragement through taxation, is a response to an instinctive wish for direct action, and taxation has the advantage over regulation and prohibition that the state is involved as a legislator prescribing the rules of the game rather than as a player. Nevertheless, there are serious problems:

(a) A carbon tax or other tax on emissions affects some industries more than others, and those who suffer most may not by other criteria be those doing the most damage to the environment. If those who suffer most are relieved or compensated, the tax loses its purpose.

(b) Enforcement may be difficult, especially if the tax is resented. Some forms of evasion, stimulated by the tax, may compound the original problem: flytipping is worse than orderly landfill.

(c) An environmental tax, like a sumptuary tax or any impost intended to influence behaviour, has an inherent ambivalence: in so far as the policy succeeds, tax revenue falls. Taxes intended to participate in economic prosperity, by contrast, yield more revenue in so far as policy is successful and prosperity increases.

(d) Economies which impose environmental taxes are likely to weaken their competitive position relatively to economies which do not.

(e) Economies which impose environmental taxes are likely to shift economic activity to economies which do not. In the world as a whole, pollution and environmental degradation may in consequence increase rather than decrease.

(f) World government, the theoretical solution to (d) and (e), is disproportionate to the problem and is in any case impracticable or generally unacceptable or both.

The approach of the European Union and Commission to environmental taxation is open to criticisms (a) to (f).

\section{A market in emission rights}

An alternative approach is to sell tradable rights to emit noxious substances or do other environmental damage. This brings into play what might be called a principle of Ricardian comparative disadvantage, since those with the greatest economic need to damage the environment have the ability and incentive to pay most for so doing.

This system mitigates the disadvantages in (a) to (f). It has been used in the United States for many years, but is not used or contemplated for use in the European Union.

\section{A tax on the use of resources}

A third form of environmental control through taxation would be a by-product of a tax on the use of resources (as recommended by Professor Grapperhaus 'Changing the tax base', Bulletin for International Fiscal Documentation 1996/11-12, p. 490). Taxes on the earnings of labour and capital in the hands of individuals would be replaced by taxes on the use of labour and capital by business ('business tax on labour and capital', hereafter referred to as ' $\mathrm{BTLC}$ '): less tax (not more, as at present) would be due in so far as labour and capital were used more frugally. The case for levying proportional taxes on the use of labour and capital, rather than graduated taxes on the results of that use, goes far beyond environmental considerations; but this could be a radical means of improving the relationship between business and the environment, since damage is or may be done not merely by particular acts and omissions but by business activity in general.

A revenue-neutral BTLC would bear more heavily than at present on financially marginal businesses and less heavily on the successful. While a shift of this kind might be beneficial for the economy and society as applied to established businesses, something more like the present system might have to be retained for businesses in their first few years: otherwise the obstacles to successful start-ups, which are already formidable, might become insurmountable.

\section{Conclusion}

There are serious disadvantages in attempts to resolve environmental problems through a head-on fiscal assault, particularly if the taxes concerned are additional and not merely substitutes for existing levies. To achieve a satisfactory solution, it may be advisable or necessary to make environmental measures an element of more extensive reforms which have their own justification on wider grounds. 